\title{
Morphological Analyses of Caseous Necrosis Correlated to CD68+ and CD8+ Cells in Biopsies of Tuberculous Pleurisy
}

\author{
Análisis Morfológico de la Necrosis Caseosa y su Correlación \\ con Células CD68+ y CD8+ en Biopsias de Pleuritis Tuberculosa
}

"Alessandra Santana; **Camila Loureiro; ${ }^{* * *}$ Aryon Barbosa Jr. \& ${ }^{* * * * * *}$ Sérgio Arruda

SANTANA, A.; LOUREIRO, C.; BARBOSA JR, A. \& ARRUDA, S. Morphological analyses of caseous necrosis correlated to CD68+ and CD8+ cells in biopsies of tuberculous pleurisy. Int. J. Morphol., 27(1):193-200, 2009.

SUMMARY: Tuberculosis is the most prevalent infectious disease in the world. Granuloma formation and caseous necrosis are hallmarks of $M$. tuberculosis infection and they represent the protective and inflammatory reactions in the infected tissues. The molecular mechanisms that mediate granuloma necrosis are still not well understood. Objectives: To immunolocalize and correlate the amounts of CD68+ macrophages and CD8+ lymphocytes to caseous necrosis extension in granulomas of tuberculous pleurisy. Methods: The study is a retrospective analysis of 30 pleural biopsies with histopathological diagnosis of chronic granulomatous pleurisy with caseous necrosis. These biopsies were classified according to necrosis intensity as minimal (N1), moderate (N2) and intense (N3). The number of granulomas was also observed and categorized as G1 (1 to 4 granulomas per section), G2 (5 to 8 granulomas per section), and G3 (more than 8 granulomas per section). Results: The means of CD68+ cells counts per $\mathrm{mm}^{2}$ in $\mathrm{N} 1, \mathrm{~N} 2$ and $\mathrm{N} 3$ categories of necrosis were $1,287 \pm 254$, $1086 \pm 181$ and $930 \pm 115$ respectively. The means for CD8+ cells were $483.7 \pm 396,366.3 \pm 43$ and $558 \pm 53$ cells per mm m in $^{2} 1, \mathrm{~N} 2$ and N3 respectively. Conclusions: There were no significant statistical correlations between necrosis extension and cell counts. In analyzed biopsies, the number of CD68+ cells was significantly higher than the number of CD8+ cells.

KEY WORDS: Tuberculous pleurisy; CD68+ macrophages; T CD8+ cells; Caseous necrosis.

\section{INTRODUCTION}

Tuberculosis $(\mathrm{Tb})$ is the most important infectious cause of death in the world that is histologically characterized by a chronic granulomatous inflammation and caseous necrosis (Bloom \& Murray, 1992). After decades with the disease in apparently control, many countries decided to reduce financial investments in politics to combat bacillus dissemination. However, the number of $\mathrm{Tb}$ cases has increased in many regions, paralleled by AIDS dissemination, increasing incidence of multi -drug-resistant M. tuberculosis (M. tb) strains and increasing migration between continents. Today, $\mathrm{Tb}$ is considered by the World Health Organization as a global emergency, responsible for more than 8 million new cases and 2-3 million deaths annually. In Brazil, approximately 110,000 new cases and 6,000 deaths occur per year (Kaufmann \& McMichael, 2005; Schluger \& Rom, 1998; World Health Organization, 2006).

After the inhalation of droplets containing the bacilli, alveolar macrophages and CD4+ and CD8+ T cells interact to form a granuloma at the site of infection, which consists primarily of macrophages and lymphocytes surrounding a central area of necrosis. Macrophages engulf mycobacteria, produce immunomodulatory cytokines and regulate the induction of Th1 cell-mediated immune response (Flynn \& Chan, 2001). CD4+ T cells are considered pivotal in protective immunity to $\mathrm{M}$. tb by secreting type 1 cytokines (IFN, TNF) and implementing cytotoxic activities, and thus failure of the CD4+ T-cell response contributes to progressive

* Escola Bahiana de Medicina e Saúde Pública, FBDC, Salvador, Bahia, Brazil.

** Escola Bahiana de Medicina e Saúde Pública, FBDC, Salvador, Bahia, Brazil. FAPESB (Fundação de Amparo à Pesquisa do Estado da Bahia) scientific initiation student program.

*** Laboratório de Patologia Experimental, Centro de Pesquisas Gonçalo Moniz, FIOCRUZ, Bahia, Brasil.

****: Escola Bahiana de Medicina e Saúde Pública, FBDC, Salvador, Bahia, Brazil.Laboratório Avançado de Saúde Pública, Centro de Pesquisas Gonçalo Moniz, FIOCRUZ, Bahia, Brazil. 
primary infection and reactivation of endogenous mycobacteria, as occurs in HIV infected individuals (Barnes et al.,1991). While CD4+ T lymphocytes are considered the most efficient cell type in host defense, $\mathrm{CD} 8+\mathrm{T}$ cells have shown to contribute to this resistance. They act as killer cells against M. tb infected targets by lysing bacilli infected macrophages via Fas independent granule exocytosis pathway and also contribute to IFN-GAMMA and TNFALPHA production (Xing et al., 1998).

The host immune response is believed to be the main cause of tissue necrosis, which may result from cytokinemediated toxicity, as well as the release of activated proteolytic enzymes by macrophages (Schluger \& Rom). Although the bacilli remain viable and evade the immune system, the necrosis can provide an environment that contributes to transmission and spread of disease.

It is known that pulmonary disease represents the great majority of $\mathrm{Tb}$ cases. However, around $10 \%$ of cases are extrapulmonary $\mathrm{Tb}$ and tuberculous pleural effusion is the most common. This pleural injury is caused by a severe delayed-type hypersensitivity reaction in response to the rupture into the pleural space of a sub pleural focus of M. tb infection (North \& Jung, 2004; Ferrer, 1997; Silva, 1993). Because pleural tuberculosis has a better prognostic than pulmonary $\mathrm{Tb}$, it has been studied as a protective immune response model (Sahn, 1988).

Developing better vaccines against the disease and finding new therapeutics to treat patients are major challenges for researches. Although many aspects of the granulomatous inflammation mechanisms are known, distinguishing the specific role of each cell in granuloma is crucial for a better understanding about $\mathrm{Tb}$ pathogenesis. We therefore performed both immunohistochemical and morphometric analyses to better understand caseous necrosis.

\section{MATERIAL AND METHOD}

This study is a retrospective histopathological analysis of 30 pleural puncture biopsies from HEOM patients with confirmed tuberculosis pleurisy. Tb diagnosis was confirmed by chest radiograph (presence of pleural fluid), Ziehl-Neelsen staining, mycobacteria culture and positive histopathology for granulomas with caseous necrosis.

By histopathological analysis, we established some classification criteria for tissue sections according to the number of granulomas and caseous necrosis extension: few (G1), moderate (G2) or many (G3) granulomas, and minimal
(N1), moderate (N2) or intense (N3) caseous necrosis, respectively (Fig. 1). Granulomas were quantified in all pleural fragments of each biopsy. Samples with 1 to 4 granulomas were classified as G1, with 5 to 8 granulomas as G2 and with more than 8 granulomas as G3. Necrosis extension was considered minimal when there were 1 to 2 areas with caseous necrosis, moderate when there were 3 to 5 areas, and intense when there were more than 5 areas with caseous necrosis in pleural fragments.

Immunohistochemistry and morphometry. The paraffin embedded tissue was dewaxed, rehydrated through graded alcohols and washed in distilled water. Five $\mathrm{mm}$ tissue sections were stained by hematoxylin and eosin. CD68+ and CD8+ cells were localized by immunohistochemistry using mouse IgG anti CD68+ (MO814, 1:200, Dako Denmark) and CD8 (M7103, 1:80, Dako Denmark). Controls slides were incubated with non-specific mouse IgG. The ligation of primary antibody to specific CD molecules was detected by LSAB System (Dako, K0690, USA).

The calculation of caseous necrosis percentage in each biopsy was performed using the formula: necrosis area/ inflammation area x 100. CD68 and CD8 positively stained cells as well as the extension of caseous necrosis were quantified morphometrically by a system and software (Leica Qwin 2.6 and Image Proplus).

Statistical analyses. Comparison among cells, necrosis and the score of granulomas in biopsies were analyzed statistically by a non parametric test. Linear regression was applied to correlate the studied parameters. Results are expressed by the means + standard errors of mean (SEM). Significance was considered when $\mathrm{p}<0.05$. Graphics and the statistics analysis were performed using the GraphPad Prism v.5.00 software (GraphPad Inc).

\section{RESULTS}

Study sample. The sample was constituted by 30 biopsies of pleural Tb patients. Among all patients, 26 (86.6\%) were men and $4(13.3 \%)$ were women. The mean \pm SD age was $33.3 \pm 15.2$ years and age range was $11-82$ years. Five biopsies were scored as G1 (1-4 granulomas), 10 as G2 (58 granulomas), and 15 as G3 (> 8 granulomas/slide).

Immunochemistry. Biopsies' analyses revealed that there is a higher number of macrophages than CD8+ cells in pleural tissue inflammation. Moreover, a peripheral distribution of T CD8+ lymphocytes was observed in the majority of granulomas (Fig. 2). This may be related to the fact that $\mathrm{T}$ 

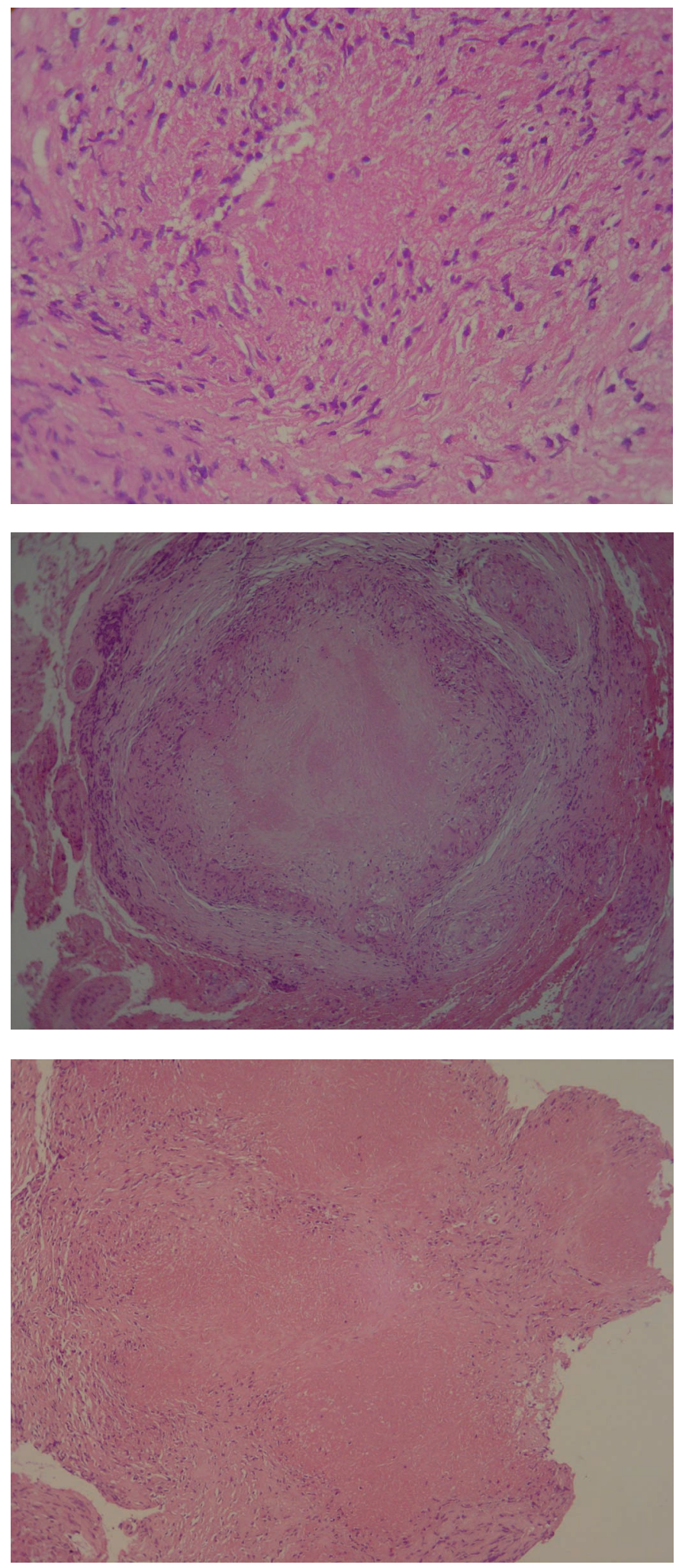

Fig. 1. Micrographs of $\mathrm{H} \& \mathrm{E}$ stain of granulomas with caseous necrosis scored as N1 (minimal) in A (10x), moderate (N2) in B (10x) and N3 (intense) in $\mathrm{C}(4 \mathrm{x})$. $\mathrm{CN}$ means caseous necrosis. Note that $\mathrm{C}$ is in lower magnification than $\mathrm{A}$ and $\mathrm{B}$. lymphocytes probably present a trend to locate in distinct regions in granulomas.

The correlation between the number of granulomas and CD68+ or CD8+ cells counts is shown in Fig. 3. The mean number of CD68+ cells was $660 \pm$ 73 in $\mathrm{G} 1,1,191 \pm 37$ in $\mathrm{G} 2$ and 1,061 \pm 61.6 in G3 group (Fig. 3A). The comparison between G1 and G2 and between G1 and G3 groups was significant, but there was no correlation among the 3 groups and CD68+ cells counts. There was no statistical difference comparing G2 and G3 groups.

For CD8+ cells, the mean number was $350 \pm 98$ in $\mathrm{G} 1,426 \pm 31.8$ in $\mathrm{G} 2$ and $522 \pm 43.8$ in G3 group (Fig. $3 \mathrm{~B})$. There were no significant differences among the number of CD8+ cells in G1, G2 and G3 graduated biopsies.

The correlation between caseous necrosis extension and CD68+ cells counts revealed that the mean numbers of CD68+ cells were 1,287 $\pm 254,1086 \pm 181$ and $930 \pm 115$ cells for biopsies classified as N1, N2 and $\mathrm{N} 3$, respectively. The mean numbers of CD8+ cells was $483.7 \pm 396$ in N1, 366.3 \pm 43 in N2 and $558 \pm 53$ in N3 (Figs. 4A and B). There is a significantly higher number of CD8+ cells counts in all 3 groups of biopsies classified in accordance with caseous necrosis extension.

The percentage of necrosis in each biopsy was quantified by morphometric analysis. Fig. 5 also shows CD68+ and CD8+ cells counts, but the comparison was with the percentage of necrosis.

There is a significant and positive linear correlation between the subjective score and percentage of caseous necrosis. In biopsies with minimum necrosis (N1), the percentage of necrosis was $1.03 \pm 0.2 \%$, and in biopsies with intensive necrosis (N3) the percentage found was $5.7 \pm 1.6 \%$ (Fig. 6).

\section{DISCUSSION}

Pleural injury is the most common manifestation of extrapulmonary tuberculosis, with accumulation of pleural fluid as the major finding. In these cases, parietal pleural biopsy is considered the most sensitive test to diagnose TB pleural effusions (Gopi et al., 2007). The presence of granulomatous reaction with caseous necrosis suggests tuberculous etiology. Granuloma presence has been accepted as a diagnosis criterion, especially in areas 

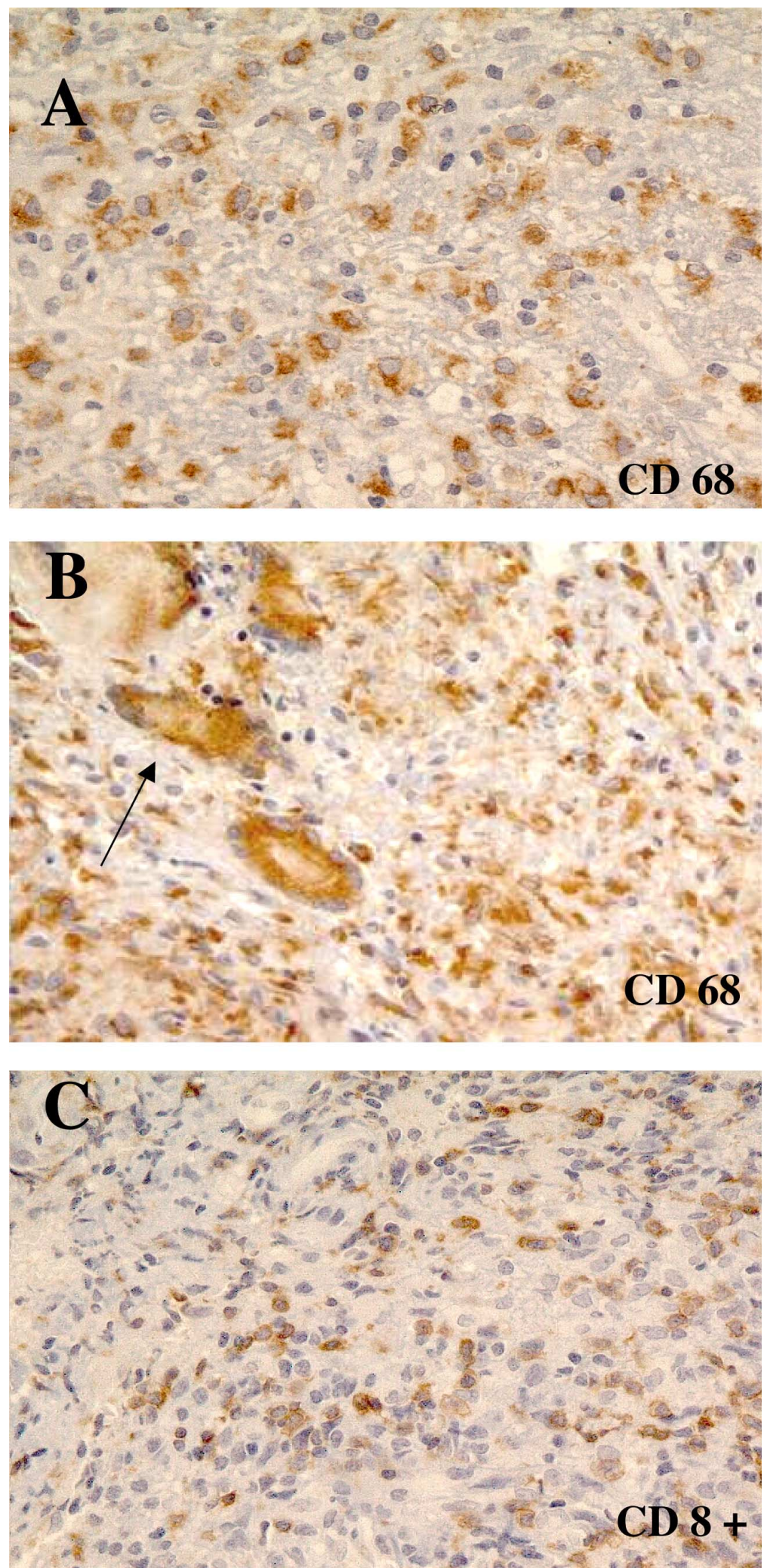

Fig. 2. CD68+ and CD8+ cells localized by immunohistochemistry in pleural biopsies of patients with tuberculous pleurisy. A shows macrophages CD68+, in $\mathrm{B}$ a detail of multinucleate giant cells CD68+ and in C lymphocytes CD8+. The arrow (B) is indicating a multinucleate giant cell. 20x. with high Tb prevalence. Other studies have considered these mentioned histopathological aspects as pleural $\mathrm{Tb}$ diagnosis (Fijalkowski \& Graczyk, 2001; Miyamoto, 1992; Valdés et al., 1998). However, there is a lack of studies in the literature emphasizing caseous necrosis and its correlation to granulomatous cells counts and morphometric analysis.

When inhaled mycobacteria arrive in the lungs, they are phagocytosed by alveolar macrophages. Lung granulocytes, $\mathrm{T}$ cells and NK T cells are arrivals that attract other macrophages and, later, $\mathrm{T}$ cells to the infectious site by a chemokine and cytokine cascade. Thus, the Th1 immune response drives the formation of granulomas which have a central area of necrosis (Ulrichs et al., 2004). Macrophages and fibroblasts, endothelial cells and neutrophils also produce proteases that mediate antigen processing, removal of cellular debris and extra cellular matrix $(\mathrm{ECM})$ and process cytokine and hormones.

While the role of GAMMA-DELTA T cells, which represents a very small fraction of total $\mathrm{T}$ cell population, is less clear in $\mathrm{Tb}$ pathogenesis, CD4+ T lymphocytes are considered the main players in immunity to mycobacteria. CD8+ lymphocytes also have been shown to contribute to this resistance to Tb. CD4+ cells produce IFN-GAMMA, which is responsible for the control of bacillary replication, and also implement cytotoxic activities. CD8+ cells secrete perforin and granzymes and also are capable of secreting cytokines such as IFN-GAMMA and TNFALPHA (Xing et al.). Some in situ analyses in M. tb.-induced granulomas show that CD4+ and CD8+ lymphocytes have different distribution. These lymphocytic aggregates are predominantly formed by T CD4+ lymphocytes in the centre of granulomas, while T CD8+ cells are less frequent and located in granuloma periphery (Gonzalez-Juarrero et al., 2001). In our study, we also observed the peripheral distribution of $\mathrm{T} \mathrm{CD8}+$ lymphocytes in the majority of analyzed granulomas. As expected, we also observed that CD68+ macrophages were frequently found in the centre of granulomas surrounding necrosis areas. In addition, our results show that the inflammatory cell phenotype in pleural tissue evidenced 
A

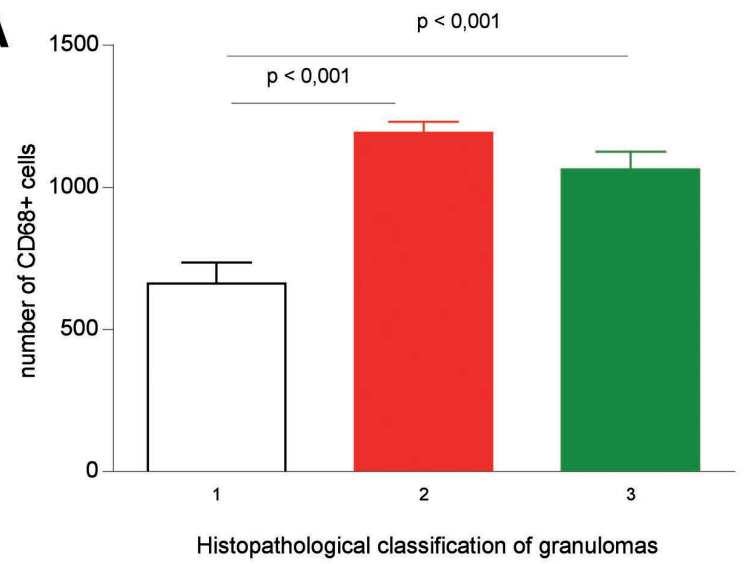

B

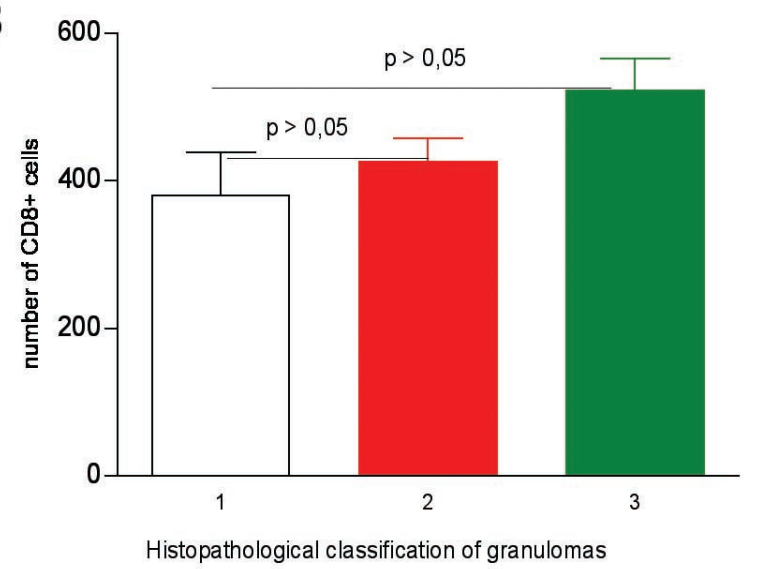

Fig. 3. Correlation between the number of granulomas per slides in G1 (1 to 4 granulomas), G2 (5 to 8 granulomas) and G3 (more than 8 granulomas) and cell counts per $\mathrm{mm}^{2}$. A. CD68+ cells. B. CD8+ cells.
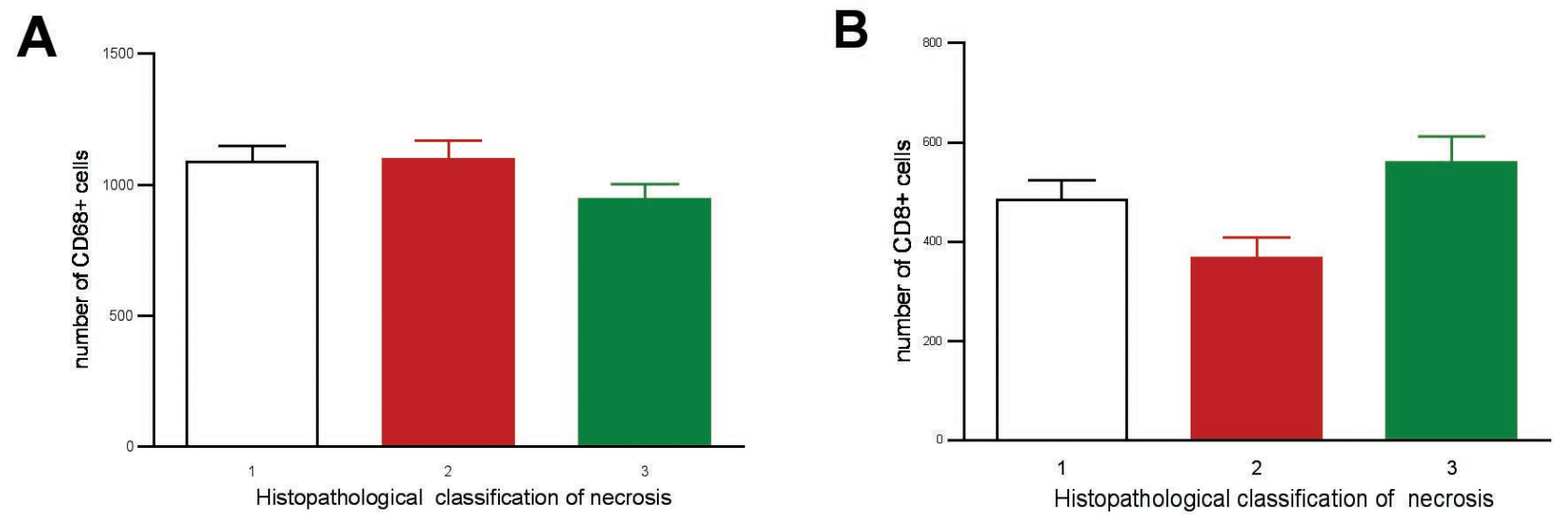

Fig. 4. Comparison between caseous necrosis intensity and the number cells per $\mathrm{mm}^{2}$ in pleural biopsies, according to histopathological classification (N1, N2 and N3). A. CD68+ cells. B. CD8+ cells.

A

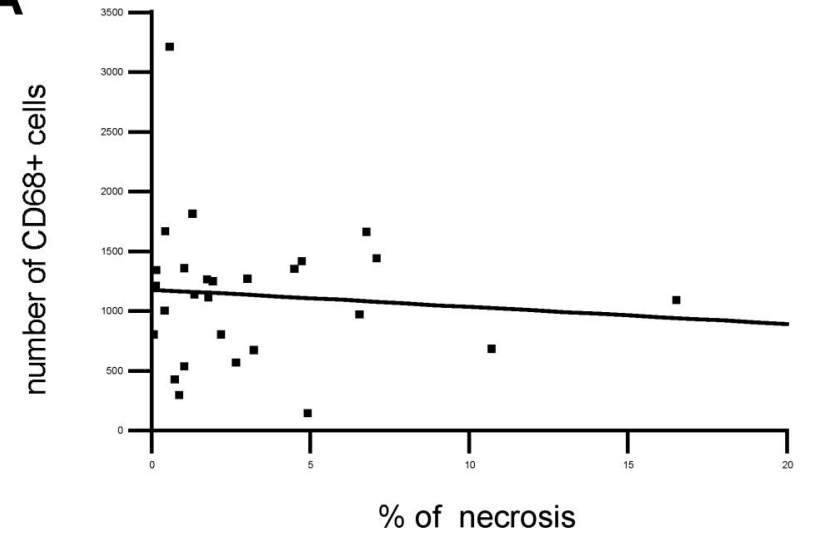

B

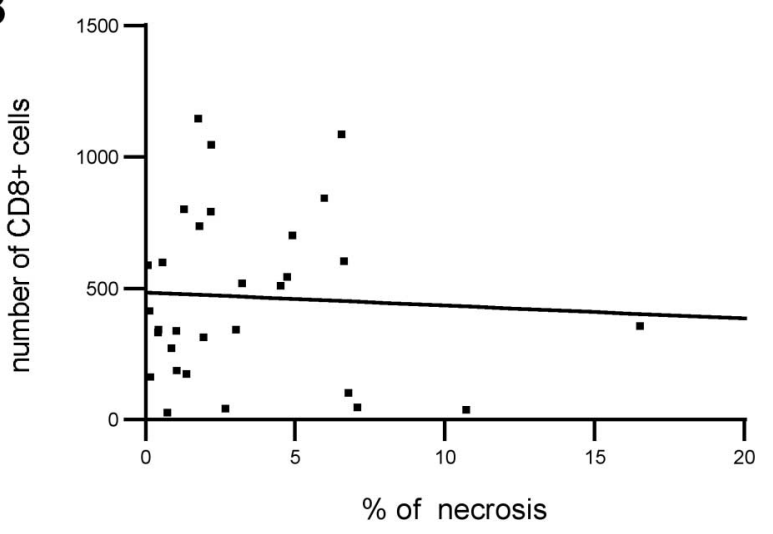

Fig. 5. Correlation between the amount of caseous necrosis obtained by morphometric anlyses and the number of cells per $\mathrm{mm}^{2}$ in pleural biopsies of pleural Tb patients. A. CD68+ cells; r2=0.008; $\mathrm{p}=0.65$ (ns). B.CD8+ cells, r2=0.003; $\mathrm{p}=0.77$ (ns). 


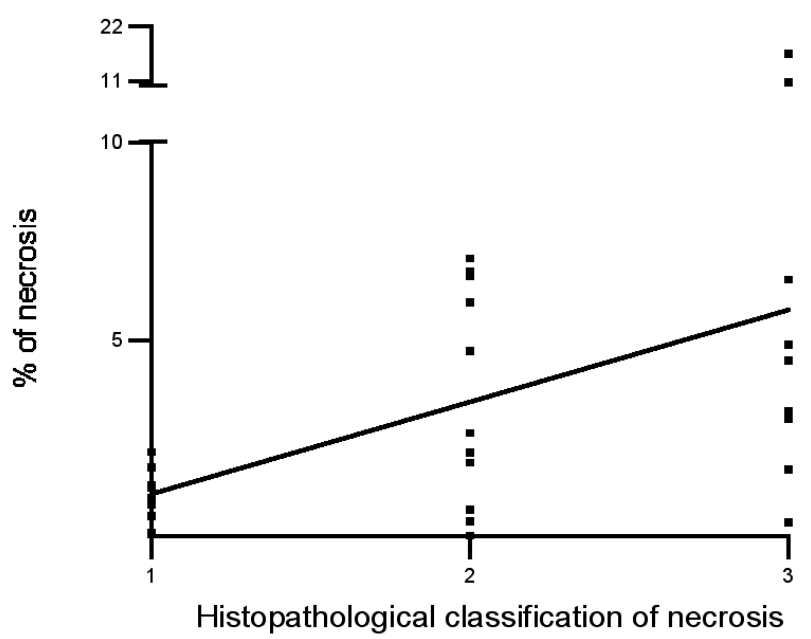

Fig. 6. Linear correlation between the two methods applied to evaluated caseous necrosis in pleural biopsies: histopathological and morphometric classifications ; $\mathrm{r} 2=0.26 ; \mathrm{p}=0.0033$.

CD68+ macrophages predominance and a lesser number of CD8+ lymphocytes.

In cooperation with $\mathrm{T}$ cells, macrophages have effective bacteriostatic or bacteriocidal activities. Within the granuloma, these cells secrete TNF-ALPHA, which has an important role in the immune response against M.tb. Some studies have shown that the increased clinical use of TNF antagonists has been associated to increased reporting of latent $\mathrm{Tb}$ reactivation (Keane et al., 2001). TNF-ALPHA is essential for the formation and maintenance of granulomas (Fenhalls et al., 2002; Ehlers et al., 2001). It is a fundamental cytokine for effective mononuclear cell recruitment, mycobactercidal activity and necrosis (Lukacs et al., 1994). This macrophage activation driven by cell-mediated immunity may cause their own destruction by cytotoxic $\mathrm{T}$ cells. Macrophages then accumulate as caseous necrosis, predominantly in the central part of granuloma where macrophages are concentrated in higher proportion. Furthermore, mycobacteria themselves may produce endopeptidases or other pro-necrotic virulence factors (Ulrichs et al.; Seiler et al., 2003).

Necrosis, which is known for more than a century as "Koch's phenomenon", is the result of T cell activity represented by delayed-type hypersensitivity reactions. Other hypothesis is that necrosis occurs at the centre of lesions that became too big to allow certain nutrients and cytokines produced by $\mathrm{T}$ cells to reach the macrophages in the centre of the granuloma (Dannenberg, 1991; Orme, 1998). Caseous necrosis and its associated progressive oxygen depletion create unfavorable conditions for mycobacterial multiplication. Thus inducing the bacilli to enter a nonreplicating latent state and, by other side, macrophage activation and CD3+ effector cell mechanisms leads to mycobacterial sterilization (Wayne \& Hayes 1996; Hemsworth \& Kochan, 1978). On the other hand, necrosis not only causes local tissue damage, such as pulmonary cavitation, but these irreversible lesions liberate high amounts of bacilli that disseminate to other parts of the body or to the atmosphere. Furthermore, necrosis may help viable bacilli to evade the immune system and be protected against chemotherapy by necrotic debris (Raupach \& Kaufmann, 2001; Florido et al., 2002).

Caseation is also associated with apoptosis of macrophages and T lymphocytes, that is an energy dependent process that involves the activation of caspases and promotes killing of intracellular M. $t b$. However, the role of apoptosis in $\mathrm{Tb}$ pathogenesis is still poorly understood. Some studies have shown that only live $M$. $t b$ can induce apoptosis, but killed $M . t b$ and mannosylated lipoarabinomannan inhibit apoptosis. As the granuloma has a continuous flux of monocytes, macrophages and other cell arrivals, the different stages of cell differentiation may be related to the type of cell death after exposure to mycobacterial products. Some authors have reported that exposure of nondifferentiated cells to PPD results in necrosis whereas differentiated cells undergo apoptosis, which confirms the possibility that human mononuclear phagocytes may exhibit both necrosis and apoptosis mechanisms (Gil et al., 2004; Rojas et al., 2000).

Granuloma quantification and cells analysis may reflect patients' immunity. It has an influence in tissue response type and possibly in morphologic presentation. Although there was no standardization, the histopathological classification in different groups was established according to the number of granulomas. The number of pleural fragments that we analyzed was variable (between 2 and 6). Other published works show that some factors may interfere in percutaneous needle biopsy diagnosis (Kirsch et al., 1997). A previous study suggested the submission of 2 to 4 samples (Chalhoulb et al., 2000) Another study demonstrated that multiple pleural fragments in two different sites increase the pleural $\mathrm{Tb}$ diagnosis. Although histopathological analyses have demonstrated differences in caseous necrosis intensity, classified as minimum, moderate and intensive, CD68+ and CD8+ cells counts were similar in different groups. Therefore there was no association between cells counts and caseous necrosis extension.

In conclusion, caseous necrosis mechanisms are not completely understood. Macrophages and CD4+ T cells play key roles in controlling the infection. Based in our results, is not true that caseous necrosis depends of the amount of macrophages at local of infection. On other hand CD8+ lymphocytes have been implicated in the resistance against 
mycobacteria (Ehlers et al.; Fenhalls et al.; Villarreal-Ramos et al., 2003), but caseous necrosis seems not to correlate to the presence of CD8+ cells. Finally, our results showed a good correlation between subjective evaluation and morphometric analysis of caseous necrosis.

\section{ACKNOLEDGMENTS}

We thank Dr. Venâncio Avancini F. Alves (Inst. Adolfo Lutz), Tania Correia (CPqGM-FIOCRUZ- Ba) for helping us with immunohistochemistry techniques.

SANTANA, A.; LOUREIRO, C.; BARBOSA JR, A. \& ARRUDA, S. Análisis morfológico de la necrosis caseosa y su correlación con células CD68+ y CD8+ en biopsias de pleuritis tuberculosa.Int. J. Morphol., 27(1):193-200, 2009.

RESUMEN: La tuberculosis es una de las enfermedades más prevalentes en el mundo. La formación del granuloma junto con la necrosis caseosa son características propias de la infección por $M$. tuberculosis y representan reacciones inflamatorias y protectoras en los tejidos infectados. No se conocen bien los mecanismos moleculares que median la necrosis en el granuloma. Los objetivos fueron inmunolocalizar y correlacionar la cantidad de macrófagos CD68+ y linfocitos CD8+ con la extensión de la necrosis caseosa, en los granulomas de tuberculosis pleural. Análisis retrospectivo que incluyeron 30 biopsias con diagnóstico histopatológico de tuberculosis pleural granulomatosa crónica con necrosis caseosa. Estas biopsias fueron clasificadas según la intensidad de necrosis como mínima (N1), moderada (N2) e intensa (N3). También se determinó el número de granulomas, que fueron clasificados como G1 (1 a 4 granulomas por sección), G2 (5 a 8 granulomas por sección), y G3 (más de 8 granulomas por sección). La cuantificación de células CD68+ por mm² en las categorías N1, N2 y N3 de necrosis fue de 1,287 $\pm 254 ; 1086 \pm 181$ y $930 \pm 115$, respectivamente. La cuantificación de las células CD68+ fue de 483,7 $\pm 396 ; 366,3 \pm 43$ y $558 \pm 53$ células por mm² $^{2}$ para N1, N2 y N3, respectivamente. No hubo correlación estadísticamente significativa entre la extensión de la necrosis y la cuantificación celular. El número de células CD68+ fue significativamente mayor que el número de células CD8+ en las biopsias analizadas.

PALABRAS CLAVE: Tuberculose pleural; Macrófagos CD 68+; Células T CD8+; Necrosis caseosa.

\section{REFERENCES}

Barnes, P. F.; Bloch, A. B.; Davidson, P. T.; Snider, D. E. Jr. Tuberculosis in patients with human immunodeficiency virus infection. N. Engl. J. Med., 324(23):1644-50, 1991.

Bloom, B. R. \& Murray, C. J. Tuberculosis: commentary on a reemergent killer. Science, 257(5073):1055-64, 1992.

Chalhoub, M.; Fidelis, R.; Barreto, A. P.; Ramos, E.; BarralNetto, M. \& Barbosa Júnior, A. A. Impacto de múltiplas biópsias em 2 pontos distintos da superfície pleural no diagnóstico de tuberculose. J. Pneumol., 26(2):55-60, 2000 .

Dannenberg, A. M. Jr. Delayed-type hypersensitivity and cellmediated immunity in the pathogenesis of tuberculosis. Immunol. Today, 12(7):228-3, 1991.

Ehlers, S.; Benini, J.; Held, H. D.; Roeck, C.; Alber, G. \& Uhlig, S. Alphabeta T cell receptor-positive cells and interferon-gamma, but not inducible nitric oxide synthase, are critical for granuloma necrosis in a mouse model of mycobacteria-induced pulmonary immunopathology. $J$. Exp. Med., 194(12):1847-59, 2001.

Fenhalls, G.; Stevens, L.; Bezuidenhout, J.; Amphlett, G. E.; Duncan, K.; Bardin, P. \& Lukey, P. T. Distribution of IFNgamma, IL-4 and TNF-alpha protein and CD8 T cells producing IL-12p40 mRNA in human lung tuberculous granulomas. Immunology, 105(3):325-35, 2002.

Ferrer, J. Pleural tuberculosis. Eur. Respir. J., 10(4):942-7, 1997.

Fijalkowski, M. \& Graczyk, J. Tuberculous pleurisy-still difficult diagnostic problem. Pol. Merkur. Lekarski., 11(65):389-93, 2001.

Florido, M.; Cooper, A. M. \& Appelberg, R. Immunological basis of the development of necrotic lesions following Mycobacterium avium infection. Immunology, 106(4):590601, 2002.

Flynn, J. L. \& Chan, J. Immunology of tuberculosis. Annu. Rev. Immunol., 19:93-129, 2001.

Gil, D. P.; León L. G.; Correa, L. I.; Maya, J.; París, S. C.; García, L. F. \& Rojas, M. Differential induction of apoptosis and necrosis in monocytes from patients with tuberculosis and healthy control subjects. J. Infect. Dis., 189(11):2120-8, 2004.

Gonzalez-Juarrero, M.; Turner, O. C.; Turner, J.; Marietta, P.; Brooks, J. V. \& Orme, I. M. Temporal and spatial arrangement of lymphocytes within lung granulomas induced by aerosol infection with Mycobacterium tuberculosis. Infect. Immun., 69(3):1722-8, 2001. 
Gopi, A.; Madhavan, S. M.; Sharma, S. K. \& Sahn, S. A. Diagnosis and treatment of tuberculous pleural effusion in 2006 Chest, 131(3):880-9, 2007.

Hemsworth, G. R. \& Kochan, I. Secretion of antimycobacterial fatty acids by normal and activated macrophages. Infect. Immun., 19(1):170-7, 1978.

Kaufmann, S. H. \& McMichael, A. J. Annulling a dangerous liaison: vaccination strategies against AIDS and tuberculosis. Nat. Med., 11(4):S33-44, 2005.

Keane, J.; Gershon, S.; Wise, R. P.; Mirabile-Levens, E.; Kasznica, J.; Schwieterman, W. D.; Siegel, J. N. \& Braun, M. M. Tuberculosis associated with infliximab, a tumor necrosis factor alpha-neutralizing agent. N. Engl. J. Med., 345(15):1098-104, 2001.

Kirsch, C. M.; Kroe, D. M.; Azzi, R. L.; Jensen, W. A.; Kagawa, F. T. \& Wehner, J. H. The optimal number of pleural biopsy specimens for a diagnosis of tuberculous pleurisy. Chest, 112(3):702-6, 1997.

Lukacs, N. W.; Chensue, S. W.; Strieter, R. M.; Warmington, K. \& Kunkel, S. L. Inflammatory granuloma formation is mediated by TNF-alpha-inducible intercellular adhesion molecule-1. J. Immunol., 152(12):5883-9, 1994.

Miyamoto, J.; Koga, H.; Kohno, S.; Matsuda, H.; Yoshitomi, Y.; Miyazaki, Y.; Kaku, M.; Miyazaki, T.; Watanabe, K. \& Oe, T. A clinical study of tuberculous pleurisy. Kekkaku, 67(7):509-13, 1992.

North, R. J. \& Jung, Y. J. Immunity to tuberculosis. Annu. Rev. Immunol., 22:599-623, 2004.

Orme, I. M. The immunopathogenesis of tuberculosis: a new working hypothesis. Trends. Microbiol., 6(3):94-7, 1998.

Raupach, B. \& Kaufmann, S. H. Immune responses to intracellular bacteria. Curr. Opin. Immunol., 13(4):41728, 2001.

Rojas, M.; García, L. F.; Nigou, J.; Puzo, G. \& Olivier, M. Mannosylated lipoarabinomannan antagonizes Mycobacterium tuberculosis-induced macrophage apoptosis by altering $\mathrm{Ca}+{ }^{2}$-dependent cell signaling. $J$. Infect. Dis., 182(1):240-51, 2000.

Sahn, S. A. State of the art. The pleura. Am. Rev. Respir. Dis., 138(1):184-234, 1988.

Schluger, N. W. \& Rom, W. N. The host immune response to tuberculosis. Am. J. Respir. Crit. Care Med., 157(3):67991, 1998.
Seiler, P.; Aichele, P.; Bandermann, S.; Hauser, A. E.; Lu, B.; Gerard N. P.; Gerard C.; Ehlers, S.; Mollenkopf, H. J. \& Kaufmann, S. H. Early granuloma formation after aerosol Mycobacterium tuberculosis infection is regulated by neutrophils via CXCR3-signaling chemokines. Eur. J. Immunol., 33(10):2676-86, 2003.

Silva, L. C. C. Tuberculose extrapulmonar. J. Pneumol., 19:837, 1993.

Ulrichs, T.; Kosmiadi, G. A.; Trusov, V.; Jörg, S.; Pradl, L.; Titukhina, M.; Mishenko, V.; Gushina, N. \& Kaufmann, S. H. Human tuberculous granulomas induce peripheral lymphoid follicle-like structures to orchestrate local host defence in the lung. J. Pathol., 204(2):217-28, 2004.

Valdés, L.; Alvarez, D.; San José, E.; Penela, P.; Valle, J. M.; García-Pazos, J. M.; Suárez, J. \& Pose, A. Tuberculous pleurisy: a study of 254 patients. Arch. Intern. Med., 158(18):2017-21, 1998.

Villarreal-Ramos, B.; McAulay, M.; Chance, V.; Martin, M.; Morgan, J. \& Howard, C. J. Investigation of the role of $\mathrm{CD} 8+\mathrm{T}$ cells in bovine tuberculosis in vivo. Infect. Immun., 71(8):4297-303, 2003.

Wayne, L. G. \& Hayes, L. G. An in vitro model for sequential study of shiftdown of Mycobacterium tuberculosis through two stages of nonreplicating persistence. Infect. Immun., 64(6):2062-9, 1996.

World Health Organization. Global tuberculosis control: surveillance, planning, financing. Geneva, Switzerland, World Health Organization, 2006.

Xing, Z.; Wang, J.; Croitoru, K. \& Wakeham, J. Protection by CD4 or CD8 T cells against pulmonary Mycobacterium bovis bacillus Calmette-Guerin infection. Infect. Immun., 66(11):5537-42, 1998.

\section{Correspondence to:}

Sérgio Arruda

Laboratório Avançado de Saúde Pública

Centro de Pesquisas Gonçalo Moniz, FIOCRUZ

Rua Waldemar Falcão, 121, Candeal, 40296-710

Salvador, Bahia

BRAZIL

Phone: +55-71- 31762232

Email: sa@bahia.fiocruz.br

Received: 05-06-2008

Accepted: 08-10-2008 